Research Article

Krzysztof Jasiecki*

\title{
The strength and weaknesses of the varieties of capitalism approach: the case of Central and Eastern Europe
}

https://doi.org/10.2478/ijme-2018-0030

Received October 8, 2018; accepted December 28, 2018

\begin{abstract}
The purpose of the article is to characterize selected theoretical and methodological advantages, controversies, and limitations of the varieties of capitalism (VoC) approach in application to Central and Eastern European (CEE) countries. It indicates the reasons for the usefulness of such an approach for the study of postcommunist capitalism in the region. The application of the VoC is considered as going beyond the dominant approaches to systemic changes in CEE in the 1990s, such as the strategy of neoliberal economic reforms and the "transitology" prevailing among political scientists and sociologists who referred to democratic patterns of change in Southern Europe. After a decade of reforms, due to different trajectories of development in the countries of the region, such interpretations lose their explanatory power. Other ways of analyzing transformations in CEE have become needed. The need for new theoretical inspirations has also been strengthened by the European Union (EU) accession of the same postcommunist countries. The accession has generated a search for a new language of description and analyses of institutional changes in all the countries of the enlarged Union. In this context, the $\mathrm{VoC}$ approach seems to fill the theoretical vacuum left by the end of the "transition" debate in the political research on CEE and provides a major post-transition research agenda and has also built a bridge between discourses which were previously separated in the political economy, neo-institutional approaches, economic sociology, and political sciences. The key advantages of the VoC approach are presented, which made these perspectives influential among researchers of institutional changes in postcommunist countries. The theoretical and analytical framework, classifications, typologies, clusters, indexes, indicators, and so on are tested and widely applied as well. Selected weaknesses and limitations of the VoC approach in the application to CEE are also analyzed. Their manifestation is the confusion associated with the use of various classifications of models of capitalism and the functionalistic character of the VoC focusing on explaining the results, but not the causes of the institution's activities, as well on institutional determinism diminishing the significant role of the social factors of change.
\end{abstract}

Keywords: the diversity of capitalism, models of capitalism, postcommunist variants of capitalism, Central and Eastern European economies

\section{Introductory remarks}

Since the turn of the 20th and 21st centuries, the dominant paradigm in comparative research on contemporary capitalism has been the varieties of capitalism (VoC) approach. According to the VoC assumptions, after the Second World War, two main models of political economy of capitalism were formed: a liberal market economy (LME) and a coordinated market economy (CME) [Hall and Soskice, 2001]. Although this dichotomy has been criticized for its simplification, it still sets the basic theoretical framework for VoC

*Corresponding author: Krzysztof Jasiecki, Centre for Europe, University of Warsaw, E-mail: k.jasiecki@uw.edu.pl 
research, and since the second half of 2000 it has also been applied with various modifications toward postsocialist Central and Eastern Europe (CEE). In the development of the VoC literature, however, there has been a certain dissimilarity in the treatment of contemporary models of the political economy of capitalism, which partly results from a different theoretical and methodological tradition of the specifics of various scientific disciplines. For example, sociologists tend to be more likely to use the qualitative typology of market economies presented by Hall and Soskice. On the other hand, economists use the statistically sophisticated typology of capitalism developing the concept of Bruno Amable. In his book, The Diversity of Modern Capitalism (2003), Amable distinguished five different models of capitalism: market-based economies, social democratic economies, Asian capitalism, Continental European capitalism, and South European capitalism.

The manifestation of the first approach is primarily research in the field of industrial relations and collective labor relations in which the dichotomous model of liberal capitalism and coordinated capitalism corresponds well with the discussion on the neo-pluralistic or neo-corporatistic system of representation of interests. An example of the latter approach is the analysis of various institutional areas of the market economy, such as the financial sector, social protection, product-market competition, and education, which are arranged in complex patterns of connections. They enable the empirical recognition of various models of modern capitalism. These models, based on extensive statistical methods and techniques, usually go beyond the LME and CME dichotomy. The researchers who use them emphasize that such features of the organization of the economy occur in different proportions in all VoC, both at the state and sectoral levels [Farkas 2016; Amable 2003].

The article characterizes selected theoretical and methodological advantages, controversies, and limitations of the $\mathrm{VoC}$ approach and its different versions in applications to postcommunist CEE countries, especially to Poland, Hungary, the Czech Republic, and Slovakia, often referred to as the Visegrad Four (V4). Due to the fact that the author is a sociologist of the economy, he also draws attention to the advantages and limitations of the neo-institutional perspective in the approach to the "new capitalism" in CEE, which he considers from a slightly different angle than economists. The structure of this paper is organized as follows: the first part (Why is VoC useful for the study of capitalism in CEE?) describes the reasons for applying the VoC approach to CEE countries against the background of changes in the theoretical interpretation of the postcommunist transformation after the accession to the European Union (EU); the second part (The main advantages of VoC in the study of CEE) presents the main advantages of the VoC approach, including the introduction of new theoretical and methodological inspirations to the analysis of changes in economic institutions in the region compared to highly developed countries; in the third part (Examples of important theoretical inspirations of the VoC: comparing CEE capitalism), based on the examples of selected typologies of capitalism, elements of the added value of the VoC approach in studies on the development of CEE are indicated; the fourth part (Selected VoC weaknesses) focuses on some weaknesses and limitations of VoC, with particular emphasis on research in the region. Final remarks (Concluding remarks) close the article.

\section{Why is VoC useful for the study of capitalism in CEE?}

There can be pointed out several most important reasons which favor the use of the VoC perspective for the "new capitalism" in CEE. In the 1990s, among economists, systemic changes in the region were considered mainly within the concept of imitative modernization which dominated in the version of the neoliberal strategy of economic reforms. Similarly, most political scientists and sociologists undertook the issue of systemic changes in the CEE adopting the normative assumptions of "transitism", referring to the political transformations in Southern Europe and in Latin America in the 1970s and 1980s [Holzer and Balik, 2009; Carothers, 2002]. The common denominator of this perspective was the assumption that Western countries provide ready-made models to follow, and the changes carried out in accordance with them trigger processes analogous to those known from developed capitalist countries. The postcommunist transformation was considered primarily as a transplantation of Western institutions and "modernization through integration" with the EU. This was perceived as similar to the process of "modernization through internationalization", 
occurring in Latin America [Przeworski, 1995]. At the same time, a tendency emerged to treat Western societies in an idealized and homogeneous way, blurring significant institutional differences among them [McMenamin 2004, p. 265].

Systemic transformation and accession of some CEE countries to the EU, economic integration with Western Europe, and global markets created a need for a new look at the postcommunist system transformation. From the perspective of some western researchers (especially those critical of economic orthodoxy), applying the VoC approach to the former Eastern bloc countries has opened opportunities to expand their theoretical preferences and empirical research onto new geographical and political arenas. It also provided an opportunity to verify previous research findings, which often gives impetus to developing theories and prompts successes in new academic fields, especially that the implementation of economic orthodoxy in the early 1990s, strongly correlated with the practice of the neoliberal Washington consensus, soon revealed its limitations in the face of qualitatively new problems of the CEE countries.

As North [2003] remarked, neoclassical economics was not created to explain issues that are of fundamental importance to the problems of the modern world, especially countries recreating elemental political and institutional rules, such as the division of power, social control, property rights, capital market, or contract enforcement. This is a static theory, based on the model of economic balance, with no place for the state and institutions, and assuming full access to information. Its mainstream focused on the functioning of developed markets, and it did not deal with the transition from a centrally planned economy to a market economy. As a result, a large scale of challenges related to the political transformation has shown that the implementation of mainstream economics in the CEE countries encounters significant restrictions. Their research had a theoretical character, resulting from the inadequacy of theories explaining the development of Western capitalism to the postcommunist conditions as well as a practical one - stemming from the specific circumstances of the transition toward market and democracy (e.g., low state capacity, lack of capital and capitalist class, domination of state property, or the construction of a new system at the time of globalization restricting the prospects of autonomous policy).

The early VoC debate also focused on highly developed countries, which resulted from their institutional stability. Focusing on this group of countries reflected their global leading role (including the academic world) along with the belief that they form a set of institutional solutions which other countries could follow. At the same time, the stability of these solutions created good premises for long-term research which were justified also by methodological considerations, such as the standardization of data and their high quality and comparability resulting from the Organization for Economic Cooperation and Development (OECD) membership. The collapse of centrally planned economies in the USSR and CEE as well as the emergence of a new geography of economic growth (particularly, the growing importance of Asian states) has, however, launched the processes of creating further variants of capitalism with different institutional and cultural characteristics. Because one of the essential features of such processes is the establishment of economic rules through political change, the analysis of new phenomena and processes created also a need for new theoretical interpretations that go beyond economic orthodoxy. Such a need coincided with the emergence or revival of research orientations in the West that were critical of the assumptions, subject, and methodology of the economic mainstream. Among them, significant influence was achieved by new institutional economics, public choice theory, evolutionary economics, and economic sociology and behavioral economics. Although these approaches show differences and theoretical and methodological contradictions, their common denominator is to enrich the areas of economic research with a multidisciplinary reflection. They also contain plenty of elements of complementarity toward mainstream economics and introduce perspective approaches to the challenges posed by modern economics. In this way, they also provide tools to reach beyond the neoclassical view of the creation of new political and economic systems in post-socialist countries. ${ }^{1}$

Researchers note various reasons which delay the development of the $\mathrm{VoC}$ approach in post-socialist countries. They mention, among others, the dominance of the neoliberal perspective in the characterization

1 Theoretical sources of new institutionalism and other concepts underlying VoC are characterized by Farkas [2016] and Morgan et al. [2010]. 
of transformation which preferred the Anglo-Saxon patterns as universal ones, the initially insignificant link between the research in CEE countries and the Western theoretical debate on contemporary variants of capitalism, as well as the relatively short period of systemic transformation hindering the formulation of in-depth generalizations [Kitschelt, 2001; McMenamin, 2004, Miller, 2010]. ${ }^{2}$ The situation changed when some of the CEE countries joined the EU. This new geopolitical and economic status quo, along with discussions on the transformation of capitalism at the beginning of the 21st century, fostered attempts to apply the VoC approach to former socialist countries. In the theoretical and geographical dimensions, a discussion was opened on market reforms in other countries and regions of the world - in Russia (the Commonwealth of Independent States, CIS) as well as in China and Vietnam [King and Szelenyi, 2005; Lane and Myant, 2007; Myant and Drahokoupil, 2011].

The process of EU enlargement to the East has contributed to changing the methodology, the definition of statistical categories, and indicators of economic and social development in the accession countries. Researchers from CEE countries gained new opportunities to participate in joint research projects with Western centers, which were financed from EU funds or other foreign grants. ${ }^{3}$ Since the end of the 1990s in CEE, such research has been part of the search for new theoretical concepts after the paradigm of transformation, characterized by the transition from the monocentric order of "real socialism" to the polycentric order of democracy and capitalism. Several Polish sociologists, summarizing the usefulness of selected theoretical approaches after a decade of radical systemic changes in CEE, emphasized that the paradigm of transformation began to lose its importance due to the transition of the region's societies to a different stage of development. Over time, the essential characteristics of the initial stage were, to a lesser extent, characterized by the processes representative of societies that were "emerging from communism". Although they still retained their national and regional specificity, they became more universal, subject to global megatrends, and CEE countries had already started to operate under "real capitalism" and "real democracy". Their membership in the EU and in the global system required a new theoretical reflection, including a comparative one [Wnuk-Lipiński and Ziółkowski, 2001, pp. 32-33].

In this context, the VoC approach seems to fill the theoretical vacuum left by the end of the "transition" debate in the political research on CEE and provides a major post-transition research agenda and also has built a bridge between discourses which were previously separated in political economy, neo-institutional approaches, and economic sociology [Mendelski, 2010, pp. 16-17; Bluhm, 2010, p. 213]. The VoC perspective became even more significant because during the postcommunist changes in CEE new ideas of social and economic order were not formulated. The demands of the governments mainly concerned the rapid introduction of systemic solutions modeled on the leading western states [Offe, 1996; Szacki, 1994; Dahrendorf, 1990; Ash, 1989; Eyal at al 1998]. As a consequence, the fundamental institutional choices became, to a large extent, the result of tactical solutions and momentary circumstances that did not result from clearly presented political programs or a deliberate reform strategy. One can discuss to what extent "leaving communism" could have been carried out differently. Despite the huge increase in knowledge in social sciences, "we still do not know how to create institutional systems that will do what we expect of them to" [North 2003, p. 151]. The global financial crisis symbolized by the collapse of Lehman Brothers in 2008 with all its consequences confirms this thesis. In this perspective, it is worth noting that one of the outcomes of the systemic changes in the CEE has been the institutional weakness consisting in the creation of an unstable frame of reference and high variability of rules, which limits the possibility of rooting new patterns of operation. ${ }^{4}$

2 For example, in Poland in the 1990s, for ideological reasons, the differences between the capitalist and socialist economies were emphasized in a way that blurred the differences between their variants. Despite the rapid disclosure of different trajectories of growth and institutional changes in the CEE countries, neoliberal elites avoided discussions on the "target" model of capitalism [Wojtyna, 2005, p. 84].

3 An example of this kind of effects of cooperation is the author's book on the Polish variant of capitalism [Jasiecki 2013], written thanks to participation in a research project comparing economic and institutional changes in Hungary, Poland, and Germany [Bluhm et al., 2014].

4 Offe [1996, p. 200] proposed to conduct a certain institutional test, involving operational feedback to show the extent of people's actions being in line with official standards as well as the ways and scope of circumventing the standards, e.g., the rules of the recruitment process for managerial positions in the public sector or law-making procedures. 
In connection with the differences in the trajectory of the development of the region's countries, the thesis was negatively verified that systemic changes in CEE can be considered in terms of one model of "Eastern European capitalism", whose institutional framework would be common to all the countries in the region [Stark 1996]. What has developed is a heterogeneous mosaic of countries, whose systems have significantly different characteristics: from pluralistic democracies, through authoritarian and oligarchic systems, to the difficulty to unequivocally qualify "hybrid regimes" [Kitschelt 2001], a political "gray zone", new forms of "non-democracy", or "non-liberal democracy" [Zielonka, 2018; Muller, 2017; Inglehart and Norris, 2016]..$^{5}$ High heterogeneity and divergent directions of systemic changes occurring in this area also apply to economic models [Aslund, 2008]. They form a spectrum of variants that go beyond the binary typology of capitalist economies of Hall and Soskice, which is confirmed by comparative studies of CEE and other EU countries, OECD, etc. [Farkas, 2016; Próchniak et al., 2016; Bluhm at al., 2014; Schneider and Paunescu, 2012; Bohle and Greskovits, 2012; Tridico, 2011; Lane and Myant, 2007; Hancke et al., 2007].

\section{The main advantages of $\mathrm{VoC}$ in the study of CEE}

The VoC approach provides new theoretical and methodological inspirations in the study of changes in CEE and in comparison to highly developed OECD countries, especially in Western Europe. It draws attention to the holistic nature of institutions that create relatively coherent patterns of complementarity in the countries of "new" post-socialist capitalism. It contains a large cognitive potential, useful in the discussion of systemic changes, and the differences of variants of capitalism in the region and in the EU. It is conducive to identifying strategic dilemmas, choices, and limitations that exist in countries seeking an "optimal" model of contemporary capitalism. As sociologist Michał Federowicz aptly pointed out, "the school of diversity in capitalism focuses on the centers of modern capitalism, but also follows the dynamics of competing with each other and internal changes. Each of them provides a language for 'latecomers', or countries [...] which joined the ranks of advanced economies with a long delay. Studying the dynamics of change, whether in the centers or in the 'latecomers', does not offer instruction, but rather shows the transformation gap expressed in immature economic institutions and helps in finding ways to breach it" [Federowicz, 2004, p. 27].

The study of individual postcommunist states, taking into account the achievements of advanced economies, requires the adoption of certain general theoretical and analytical framework useful for various comparisons - national, sectoral, problematic, etc. Without such a framework, the focus on specific countries prompts to look for specific explanations and concepts, resulting in difficulties in international comparisons, and generalizations are virtually impossible [Wojtyna, 2005, p. 95]. The VoC approach counteracts these kinds of threats due to setting its findings against the background of universal comparative research of highly developed countries, especially that the VoC approach provides a conceptual and analytical framework: a conceptual grid, statistics, classifications, typologies, clusters, indexes, indicators, measures, and so on. Some of them become both elements of academic discourse and provide language and tools useful in the public debate.

Among the manifestations of such inspirational uses, one can identify significant comprehensive literature and comparative databases in the area of industrial relations, e.g., Reports on industrial relations in Europe or the European Participation Index and important research centers, such as the European Industrial Relation Observatory (EIRO), the European Trade Union Institute (ETUI), and Eurofound. Periodic meetings of researchers - the SASE Annual Conference (alternately in Europe and on other continents) and specialized magazines, e.g., the Socio-Economic Review or the Warsaw Forum of Economic Sociology in Poland - are of a more general nature, including an extended theoretical context. Expanding the issues onto other states and including further groups of researchers create additional cognitive challenges,

5 On the theoretical and methodological aspects of research on postcommunist undemocratic "hybrid regimes" see Holzer and Balik [2009]. The book by the Czech political scientists can be a good starting point for discussions on the specificity of "illiberal democracy" in the CEE countries and the impact of policy on the economy. 
influence the methodology, and modify the nature and scope of generalizations which must also take into account the complexity of the institutional architecture of modern capitalism. Such tendencies are reflected in significant collective works such as The Oxford Handbook of Comparative Institutional Analysis.

The VoC approach integrates the results of research of various research disciplines, such as political science, sociology, economy, history, law or psychology, and others, on the basis of the neo-institutional approach; the deficit of which is particularly pronounced in the public debate in the countries of CEE. At the same time, it provides theoretical and empirical tools that enable the characterization of both similarities and differences among countries and groups of countries in the region. Every economy has specific capabilities and coordination mechanisms that correspond to what companies and governments do [Hall and Soskice, 2001, p. 35]. As a result, the development of the VoC approach, including some alternative concepts of diversity of capitalism, has proved to be inspiring also for postcommunist countries [Próchniak et al., 2016; Farkas, 2016; Bohle and Greskovits, 2012; Schneider and Paunescu, 2012; Nolke and Vliegenthart, 2009, Hancke et al., 2007, Lane and Myant, 2007].

In this respect, profuse literature, related to the application of $\mathrm{VoC}$ in postcommunist countries, already exists. Mendelski [2010, p. 11] divided this literature into four kinds of analyzes: 1) single-country case studies (for example, Czech Republic or Poland); 2) comparative case studies (Estonia versus Slovenia as model antipodes and a group of countries, such the Baltic republics versus Central European countries); 3) static comparative analysis (group of countries from point of view selected indicators, e.g., stock market capitalization, proportion of foreign direct investment [FDI], industrial relations, and so on are compared at a certain point in time); and 4) dynamic comparative analysis, which includes several countries over time and are able to capture dynamics and change to a certain extent, but unfortunately are relatively rare. The last of these methods are most promising for the analysis of capitalist diversity, especially in the mediumand long-time perspectives. The analyses mentioned above are all the more useful, because the global crisis of capitalism forces the search for new political, institutional, and social solutions which provide a possibility to overcome it. In CEE, the crisis overlapped with the depletion of economic development strategies after the collapse of state socialism.

Concerns about slowing down or halting the development convergence of the countries of the region compared to the leading EU states were the symptom of this phenomenon. Since the euro area crisis in CEE, they have been discussed in terms of the middle-income trap and the scenario of entering in a new way into the role of the "internal periphery" of Western Europe [Jasiecki, 2013; Grosse, 2016]. These fears are justified by the subordinate position of the countries in the region in the international division of labor, the key role of FDI and cohesion funds from the EU in financing investments, their lower quality of corporate management and labor relations, low innovation, as well as building comparative advantage mainly on the basis of low labor costs and labor-intensive industrial products with a low share of high technologies [Lane and Myant, 2007; Nolke and Vliegenthart, 2009; Farkas, 2016; Myant and Drahokoupil, 2011; Bohle and Greskovits, 2012]. At the same time, if we refer to the Amable typology, the course of the global crisis is a kind of test for various models of capitalism in the EU countries, for example, it characterizes which of its European variants have greater long-term development prospects.

Another strength of the VoCapproach is to draw attention to national, sectoral, and social responses to the crisis and the challenges of globalization, including the formulation of public policies that are characterized internationally. It also provides useful analyses of translating national interests into international relations. These interests are usually rooted in competitive institutions and models of capitalism, which explains to a large extent, among others, divergences in the policies of the governments of Germany, France, and the United Kingdom in the EU as well as those of CEE countries. Significant divergences occurred in the past, among others in connection with the adoption of the Maastricht Treaty and the development of the common market, the priorities of multi-annual EU budgets or service directives, and later also after posteuro crisis such as the fiscal pact or the banking union [Farkas, 2016; Schmidt and Thatcher, 2013]. For CEE countries, research that characterizes and compares different policy options can be useful in discussions about further reforms and changes in the model of capitalism. The consequences of the global economic crisis, due to its structural nature, as well as environmental issues, the energy supply, migratory pressure, and demographic problems, are likely to cause further diversification of capitalism in the EU. 
According to the author of Models of Capitalism in the European Union. Post-crisis Perspectives, "Differentiated integration is not a transitory deviation from ideal situation to be achieved but rather a method for handling the differences" [Farkas, 2016, p. 505]. The doubts and controversies surrounding the further application of this method have been illustrated by Hungary since 2010 and by Poland since 2015, when the governments changed the economic policy and the state system, including the correction of the rules of institutional complementarity and coordination. The VoC perspective creates the possibility of undertaking this issue matter-of-factly, in a way that goes beyond the ideological confrontations of the 1990s. Especially that the fact that there are different variants of capitalism is much more visible. There are also further proposals for typological characterization of the countries of the region, e.g., the model of capitalism in the Baltic republics referred to as the flexible market economy (FME) [Kuokstis, 2011]). After several decades of systemic changes, we have already learned a lot about the successes and limitations of the new economic models in postcommunist countries. The membership of CEE countries in the EU (and also in the OECD) provides an opportunity for their multidimensional comparisons. During the delegitimization of many neoliberal economic assumptions, such analyses may contribute to the discussion on the optimal model of the economy and the assessment of the effectiveness of various variants of capitalism. The concepts of coordination and complementarity, analyses of key institutions, and typologies of capitalism allow to identify inconsistencies and systemic dysfunctions and to indicate possible scenarios of change.

\section{Examples of important theoretical inspirations of the VoC: comparing CEE capitalism}

The best known manifestation of the usefulness of the VoC approach in application to CEE is the debate on models of "new" capitalism in postcommunist countries. In order to approximate the cognitive values of such a discussion, the typologies of capitalism in the region have been selected that are relatively often referred to in the literature. A new proposal has also been indicated - one that has been presented by Farkas, who placed CEE within the overall characteristic of the models of capitalism in the EU. Based on the key findings of the referenced publications, several conclusions can be drawn regarding their merits and usefulness (as well as the limitations, which is presented later). The typologies referred to are an example of the application of the VoC approach as an analytical framework to classify economic institutions in postcommunist countries. They have a methodologically diverse character: qualitative [King and Szelenyi, 2005], qualitative-quantitative [Nolke and Vliegenthart, 2009, Bohle and Greskovits, 2012], and quantitative [Farkas, 2016; Schneider and Paunescu, 2012].

They draw attention to the different aspects of the differences in capitalism in the CEE countries. Along with Hall and Soskice's and Amable's most frequently discussed proposals in the literature, which are usually a reference system for such proposals, they expand the problem area and the theoretical framework useful in the analyses of contemporary capitalism. All the cited concepts show the overly narrow nature of the dualistic typology that was presented by Hall and Soskice [Bluhm et al., 2014]. This typology does not adequately address the specifics of the subject of research due to the heterogeneity of system solutions in the region as well as the dynamics of changes in the state institutions and in the economy. For example, the "strategic coordination" used by Hall and Gingerich [2004] in the form of a linear continuum on a scale of values from low to high has few equivalents in the postcommunist countries that began radical systemic reforms not known in this scope in the West. In some countries of the region, attempts are being made to partially reverse them. The attempts are so significant that even after several years of membership in the $\mathrm{EU}$, the nature of strategic coordination has been subject to anti-liberal and statist redefinitions, in Hungary since 2010 and in Poland since 2015 [Bałtowski and Kwiatkowski, 2018; Błaszczyk, 2016]. As a result, some researchers propose different typologies of postcommunist economies that refer to different theoretical and methodological assumptions. They recognize that due to the historical specificity of the ECC, it is difficult to directly apply the VoC approach to the conditions of this region. 
Table 1. Summary of selected VoC literature on postcommunist countries

\begin{tabular}{|c|c|}
\hline Publications & Main conclusions \\
\hline $\begin{array}{l}\text { King and Szelenyi } \\
\text { [2005] }\end{array}$ & $\begin{array}{l}\text { The VoC approach can be applied to CEE as a framework of analysis, but it has to consider postcommunist } \\
\text { similarities (importance of backwardness, lack of working-class pressure) which are more important than the } \\
\text { respective differences in terms of VoC typology. In the form of Weberian ideal types, three variants of capitalism } \\
\text { are identified: 1) capitalism from without; } 2 \text { ) capitalist from above; } 3 \text { ) capitalism from below. The first type they } \\
\text { have, liberal political institutions and their economic development, is based on foreign capital (Czech Republic, } \\
\text { Hungary, Poland). The second type has authoritarian power and patrimonial economic systems with patron- } \\
\text { client ownership networks (Russia, Ukraine). The third type has totalitarian political regimes in the process of } \\
\text { selective liberalization, and hybrid economic systems dominated by state-led development with the supporting } \\
\text { role of private business (China, Vietnam). }\end{array}$ \\
\hline
\end{tabular}

Nolke and The VoC approach directly by Hall and Soskice dichotomy applied to CEE leads to the thesis, where the Vliegenthart [2009] identification of individual institutional parallels between CEE capitalism and either the CME or the LME model is misleading. CEE signifies the emergence of the new third basic variety, a "DME" type of capitalism. In DME, a single universal explanatory factor is the essential role of foreign capital, which has a huge impact on coordination mechanism dependency on intrafirm hierarchies within transnational enterprises, system of corporate governance, finance system, industrial relations, educational and training system, and transfer of innovation.

Schneider and $\quad 26$ OECD countries moved toward the liberal market model in longitudinal data (1990-2005) and the cluster Paunescu [2012] analysis, which describe five clusters with institutional configurations: state-dominate economies, CMEs, hybrid economies, LME-like economies, and LMEs. The types of capitalism are more varied and more dynamic then the VoC approach suggest. Poland, Hungary, and the Czech Republic have mixed hybrid economies in a process of transformation. The cluster of hybrid economies has a heterogeneous composition and should not be considered a distinct type of capitalism. The same cluster includes also so different countries such as Japan, Norway, Italy, and South Korea.

Bohle and Greskovits The VoC approach is difficult to apply to CEE as institutions are still not consolidated. Four types of capitalist [2012] systems, based on institutional configurations and performances, are identified: neoliberal Baltic countries, Balkan countries, Welfarist Visegrad countries, and Corporatist Slovenia. Capitalist diversity in CEE is explained by six dimensions of the Polanyian origins: democracy representation/ungovernability, government accountability/state captures, corporatism: interest mediation/rent seeking, welfare state: protection/ pauperization, macroeconomic coordination: stability/straightjacket on development, market efficiency/ commodification.

Farkas [2016] The VoC approach (in Amable's version) is applied to the classification of the models of capitalism to the UE-25 states, including CEE. In the form of the clusters, an empirical analysis is identified: the Nordic model, NorthWestern economies, Mediterranean Europe, and the post-socialist countries. The combined clusters essentially correspond to the four models that crystallized from the old EU member states also with CEE. According to this typology, individual clusters have their subclusters. In the case of CEE, the following are identified: the Baltic states, the Visegrad countries [and Hungary's separate path since 2010], Slovenia, and South-Eastern Europe (Romania, Bulgaria and Croatia).

CEE, Central and Eastern European; CME, coordinated market economy; DME, dependent market economy; EU, European Union; LME, liberal market economy; VoC, varieties of capitalism.

In the discussion about new variants of capitalism, some researchers also use the characteristics formulated on the basis of sociology and political science, regarding political strategies of the elite types of political and economic institutions or attributes of social structure, e.g., the role of domestic bourgeoisie [King and Szelenyi, 2005]. The authors who are inspired by the classifications of Max Weber's ideal types and the triad of core institutions of Karl Polanyi recognize that the level and distinctness of CEE development require attention to other aspects of institutional changes in comparison to Western countries, as democracy representation, interest mediation, government accountability, and market efficiency [Bohle and Greskovits, 
2012]. ${ }^{6}$ A different method is used by economists referring to Amable's typology of capitalism. They create clusters that generalize the features of countries with similar institutional configurations, which gives the opportunity to compare them in detail in selected time sequences to other EU countries [Farkas, 2016; Próchniak et al., 2016] or OECD [Schneider and Paunescu, 2012]. The application of the VoC approach to postcommunist countries has also contributed to the emergence of another theoretical interpretation of this issue.

In addition to the mainstream VoC research embedded in the tradition of new institutionalism and neoclassical economics, references to the competitive concepts of the dependency and world-system theory appeared. A manifestation of this trend is studies highlighting the subordination of this region to highly developed Western countries [King and Szelenyi, 2005; King, 2007; Nolke and Vliegenthart, 2009; Myant and Drahokoupil, 2011] as well as its peripheral political and economic role in the EU [Berend, 1996; Bohle and Greskovits, 2012]. The coexistence and competition of the two theoretical strands are indicative of fundamental dispute on the results of the transformation in CEE. This is due not only to the existing inconsistencies and contradictions in the application of the $\mathrm{VoC}$ to postcommunist countries. The explanatory strengths of both theories are complementary and therefore not simply substitutable one for the other [Bluhm, 2010, p. 198]. The key feature of the VoC approach is the multidimensional comparison of the institutions of the CEE countries with the economies of developed capitalism.

At the same time, the structural perspective of the world-system theory draws attention to the peculiarities of the former socialist countries, such as path-dependent institutions and communist and pre-communist legacies. Explaining capitalist diversity and institutional change in CEE must include diverse historical and future variables, which can be internal (such as national state and structural legacy) or external (IMF, UE, TNCs). For example, cluster analyses developing the Amable typology indicators concentrate on internal factors of economic growth. They allow a relatively precise identification of features of economic institutions and their changes in the CEE countries against the background of comparisons with highly developed countries. Their conclusions confirm the often expressed belief that "inconsistencies in institutional design within particular areas as well between these areas. [1/4] the institutional ambiguity of the nascent post-communist capitalism that makes the process of institution-building still a work-inprogress" [Próchniak and Rapacki, 2016, p. 44]. At the same time, such institutional incoherence is one of the key elements of the structural weakness of CEE countries in relations with development centers in the EU. This is a situation that reduces the chances for real convergence of EU regions and confirms the thesis "that differentiated integration is not a transitory deviation from the ideal situation to be achieved, but rather a method for handling the differences" [Farkas, 2016, p. IX].

In turn, new research referring to the sociological and economic categories known from the theory of the global system, such as the structural dependence of peripheral countries on the capitalist center, accentuates the different trajectories of development of former communist societies during the process of transition based on their socioeconomic systems. In this approach, the separateness of these trajectories, the influence of external factors, and the place in the international division of labor have fundamentally influenced the character of the capitalist institution in CEE. In practice, even the relatively most successful economies in the region have returned to the role of the periphery of the world system, the same role they played before the Second World War. It was not a coincidence that the former president of the Hungarian Academy of Sciences described the location of CEE countries as Detour from the Periphery to the Periphery [Berend, 1996].7 While referring to such interpretations, the typology of King and Szelenyi shows that the interplay between different trajectories of "coming out of communism" and the influence of external

6 Bohle and Greskovits's modified typology characterizing the varieties of industrial relations within the CEE countries after EU accession 2004-2008 was applied in the report of the European Commission on Industrial Relations in Europe 2012. Becker [2009] presented a similar way of thinking about the types of political economy. In Poland, the work of the Gardawski team [2013] is an example of the use of the Becker typology.

7 In the world-system theory, the Soviet Union and CEE countries ruled by communist parties were considered as autonomous semi-peripheries that tried to achieve the status of a global center by means of classical mercantilism. The new applications of Wallerstein's schemes of the stratification of the world order include CEEs in "semi-peripheries" encompassing the V4, the Baltic republics and Russia, and consider Belarus, Ukraine, and most of the Balkan states as "peripheries” [Willis, 2005, pp. 72-75]. 
factors has brought diverse effects in the countries of the region: from the form of liberal capitalism in some countries to the form of patrimonial and oligarchic systems in others. According to this interpretation, transformative deindustrialization was replaced partly by reindustrialization implemented mainly by TNCs, which was, especially Central Europe, provided with relatively well-educated and cheap workforce and the opportunity of investing close to the western markets. The participation of foreign investors in the region soon became bigger than in the 1960s in Latin America and other "Third World" countries, while theories of "dependent development” were being formulated [King and Szelenyi, 2005, p. 210; Lane and Myant, 2007; Myant and Drahokoupil, 2011]. ${ }^{8}$

The coexistence and competition of the two theoretical strands produced as a result, among other things, the concept of Nolke and Vliegenhart [2009] who distinguished the new subregional variation of capitalism in V4 - "the dependent market economy" (DME). Its main distinguishing feature is the key role of foreign capital in the coordination of the economy in the region, going beyond the assumptions of the CME-LME dichotomy. The most important (although criticized for excessive generalization) value of this concept is to draw attention to the system specificity of the countries of the region, ignored by other research orientations. According to Nolke and Vliegenhart, there are three basic criteria of economic separation specific to DME: 1) the formation of alternative mechanisms of economic coordination; 2) the existence of a stable bundle of complementary market institutions; and 3) the emergence of a characteristic set of comparative advantages. This way of analyzing CEE has become a reference system also for other projects that develop the DME issue. ${ }^{9}$

\section{Selected VoC weaknesses}

The discussion around the VoC approach has drawn attention to the various weaknesses of this research perspective. Although it has become one of the central comparative theories of political economics and economic sociology, it has also caused widespread polemics and criticism. Both the key idea of capitalism variants and the reasons for their separation and the main distinguishing features of the models are negated. There are also formulated alternative typologies of capitalism resulting from the development of theory as well as its application in other regions of the world. For the purpose of the article, the VoC approach and criticism have been selected while taking into account general issues as well as those concerning CEE countries. For example, terminological confusion associated with the use of different classifications of models of capitalism is often criticized. Researchers constructing such classifications use different terminologies as well as criteria, which translates into the numbers of distinguished types (although the majority of proposals are between two and five models). The models of capitalism are variously characterized. Some researchers include models of capitalism in a narrow way, focusing on economic factors, and others take into account also social and political or technological dimensions [Wojtyna, 2005]. Constructing a typology of capitalism referring to various theoretical assumptions and methodological criteria, different qualitative as well as quantitative operationalization of the VOC approach has created another source of ambiguity. In subsequent concepts, various variables and indicators are taken into account. Due to the fact that many different variables are chosen to explain variety, sometimes one and the same country is put in different clusters of countries [Bluhm, 2010].

The diversity of the typology of capitalism is disputable also because of the evolution of key institutions, which causes globalized economies to be, in a wide range, of mixed nature, deviating from the "pure" variants of the market economy [Lubbe, 2010, p. 56]. In addition, the literature includes other concepts and typologies, such as those regarding Asian capitalism, which introduce new dimensions of the analysis taking into account the different modes of coordination of economic activities [Witt and Redding, 2013; Zhang and Whitley, 2013]. The VoC perspective is also criticized because of excessive generalizations,

8 Another concept of the trajectory of postcommunist transformation is presented by Bohle and Greskovits [2012].

9 The load-bearing capacity of such a perspective was emphasized in 2017, among others, in the French journal Revue de la regulation, which announced the preparation of a special thematic number on "Dependent Capitalism" in Central and Eastern Europe: Theoretical foundations and diversity of national trajectories. 
often showing that empiricism differs from typological assumptions. The great theory ignores details. For example, the Scandinavian countries can serve here as an example; they are usually indicated in the literature as a variant of coordinated capitalism, although they created patterns of innovation and information technologies comparable to the Anglo-American model [Amable, 2003; Castells and Himanem, 2009]. Similarly, the difference in levels and types of dependency from MNCs among the CEE countries is so significant [Bluhm, 2010].

The fundamental controversies arise from the fact that generalizations and conclusions resulting from the VoC research were initially limited to a relatively small group of Anglo-Saxon states, Western European countries, Japan, and South Korea. There were therefore doubts about the universal nature of VoC and the question whether this approach could be useful in studying lower developed economies, including CEE, and if so, to what extent [Iankova, 2010; King, 2010; Miller, 2010]. When applied to the CEE countries, such doubts are even more justified as they concern economies characterized for the most part as the "first periphery of the global capitalist system" (I. Wallerstein), "the most durable European periphery" (I. Berend, G. Ranki), the "European periphery of secondary serfdom and penetration of capitalism" (F. Braudel), "a mixture of primitivism and imitation of the West" (P. Anderson), "an area of normal nondevelopment” (R. Brenner), “colonial development” (M. Małowist), or "hybrid development” (W. Kula) [see Sosnowska, 2004]. Also, modern qualifications of CEE as "emerging markets" or "DME" indicate that in the fundamental institutional and structural dimensions, there exists the awareness of their long-term separateness. VoC characteristics are often based on models generalizing the directions of institutional and social changes on a regional scale, not in individual countries. Their application to the needs of specific countries involves, among other things, the need to embed the studied tendencies in a specific historical context, particularly important in the countries of the region, which in the period crucial for the creation of modern capitalism, did not constitute independent states. Such circumstances are significantly different from the premises that shaped Western societies considered under the $\mathrm{VoC}$ approach. This perspective did not deal with countries subordinated for centuries to the interests of other states and/or those which after the Second World War created alternative political variants. This situation is reflected in the concepts of the trajectory of developing ways of "getting out of communism", etc.

These issues are not taken into consideration in the countries of the developed market economy. "VoC is ahistorical. Part of the appeal of VoC is that it provided a 'soft-rational choice' framework [1/4] This approach is based on a static equilibrium that, by its nature, attempts to explain differences between countries based on their different economic tendencies stemming from their institutional configurations. However, the differences between the advanced capitalist countries can only be understood in terms of the historical evolution of substantially inter-dependent economic activity in the emerging nationally-bound capitalist systems" [King, 2010, p. 1]. The ahistorical approach shows that the genesis and functioning of new capitalism in CEE is specific, resulting from relatively frequent and radical political changes, low stability, and overlapping changes to earlier institutional configurations of a completely different nature than in Western countries, such as the postcommunism heritage. These patterns and configurations co-occur with new tendencies of a high degree of influence resulting from globalization and integration with the EU. They have never before transpired anywhere in the form of such accumulation of profound political, economic, and social changes. Identifying them as "patchwork capitalism" or "hybrid capitalism" describes the effect of these changes, but does not explain their causes or development in any wider sense.

Comments of this kind can also be linked to other repeated allegations that point to the various limitations of VoC. They illustrate some general limitations of this theoretical perspective, which, however, are particularly pronounced in CEE research; of these, the following are especially worth mentioning:

- Functionalist focus on explaining the activities of the institutions, rather than on the reasons for their entity and development.

- The tendency to institutional determinism, which diminishes the role of both the state and the interests of elites and social classes as factors of changes.

- Excessive focus on previously shaped dependency paths and the loss of important elements of the dynamics of economic change.

- Minimizing endogenous national resources and their differences - regional, sectoral, and social ones. 
- Focusing on manufacturing sectors and underestimating the growing role of services in the economy [Hancke et al., 2009].

- Being balance oriented, which downplays conflicts and contradictions.

- Limiting the enterprise to the role of "institution taker", accepting development impulses from the outside; itself not being autonomous or creative enough.

- Considering state institutions with not enough regard for external links, in a way that diminishes the strength of both political actors working toward neoliberal convergence and globalization and their opponents.

- Ignoring the problems of social inequality, discrimination against women and ethnic minorities, etc.

Within the VoC approach, not many problems important for CEE, including various aspects of the legacy of communism (such as the role of informal connections), investment capital deficit or the weakness of the middle classes, and the structural consequences of such phenomena, have not been addressed. In addition, they are crucial for explaining the emerging variants of capitalism in CEE. The "political capitalism", organized by the old and the new elites, as well as the cross-border activity of foreign investors quickly increasing their share in the region's economies, enabled also by the accession conditions of the $\mathrm{CEE}$ countries to the EU, has become a substitute for capital deficit and capitalists. Some researchers even compare the effects of their actions to the creation of "comprador capitalism" known from postcolonial "Third World" countries [Eyal et al., 1998; Myant and Drahokoupil, 2011]. In such circumstances, the main distinguishing feature of the $\mathrm{VoC}$ approach, which is the concept of institutional complementarity, has only limited exploratory power in CEE. Complementarity is difficult to create in times of turmoil, rapid political and socioeconomic change, low state capacity, and diverse interests of actors. Postcommunist transition demonstrates that institutional complementarity, as a synonym of positive synergy effects, is a long-term project. Transition economies experience rapid institutional change. But before the 2007-2008 crisis, probably only Slovenia and Estonia developed coherent institutional systems [Mendelski, 2010, p. 24].

\section{Concluding remarks}

The VoC approach is and will most probably remain in the coming years a dominant paradigm in research into modern capitalist economies. It has a multidisciplinary character that integrates the results of research of various research disciplines. The theory and methodology of VoC are well embedded in the debate on contemporary capitalism and have provided so far the most useful framework and analytical tools to study its new variants of capitalism in CEE in a comparative perspective. The study of systemic changes in the VoC categories is all the more useful since, from the early 1990s, mainly the advantages of the Anglo-Saxon model were emphasized in Poland and other countries of the region, which marginalized the differences between the different variants of capitalism. A similar effect was also caused by the accession of some of the region's countries to the EU, which favored thinking in terms of a uniform "European model". In this context, research on various variants of the economy in the Union allows to more precisely indicate the choices, dilemmas, and limitations facing CEE countries in searching for the optimal model of capitalism [Wojtyna, 2005, p. 193].

In this region, there are forming variants of capitalism with very different political, institutional, and cultural characteristics. The VoC perspective opens up the possibility of objectively addressing this issue in a way that goes beyond the ideological confrontations of the 1990s. High heterogeneity and divergent directions of systemic changes in CEE create a spectrum of economic models that go beyond the binary typology of Hall and Soskice's capitalist economies. Application and modifications of the VoC approach to postcommunist countries indicate the search for a new conceptual and terminological instrumentation of the analysis of this issue. Expanding the field of comparisons and discussions also sheds new light on earlier arrangements regarding both $\mathrm{VoC}$ (e.g., the role of institutional complementarity) and the specificity of the region in question as well as the impact of "path dependency". Especially that the global economic crisis that started in 2008 not only has served as a practical test for various models of capitalism but also forces 
the search for new political, institutional, and social solutions that provide opportunities to overcome it.

The dynamic development of the VoC-inspired research has provided new theoretical and methodological impulses [Hancke et al., 2009] and has built a bridge between discourses which were previously separated in the political economy and economic sociology. This is a particularly important perspective during the global crisis, which questions the theory of the "best" model of capitalism and promotes comparisons of its competitive variants. The course and consequences of this crisis have led, among other things, to a renewed discussion on the convergence and divergence of directions of economic development, as well as to divisions into the core and the periphery of the EU. The application of the VoC approach to postcommunist countries has also changed the ways of the theoretical interpretation of this issue. In addition to the mainstream of VoC research embedded in the tradition of new institutionalism and neoclassical economics, references to the competitive concepts of the dependency and world-system theory have appeared.

The coexistence and competition of the two theoretical strands are also indicative of a fundamental dispute on the results of the transformation in CEE. Research developing Amable's typologies and indicators shows the ex-post institutional gap of the countries of the region in comparison to highly developed economies. They emphasize the "hybrid" or "patchwork" character of most institutional configurations in CEE. They often provide conclusions and recommendations indicating the need for reforms raising the institutional standards of the countries in this region to international standards conducive to economic development. In contrast, interpretations inspired by the world-system theory focus more on the analysis of different historical trajectories of the development of postcommunist countries during the process of transition and the causes and consequences of their subordinate place in the international division of labor. They prove that the identification of institutional parallels between CEE capitalism and the Western models of capitalism is partly misleading. According to this point of view, former communist economies are mostly subregional new variations of capitalism: "dependent market economies" or "semi-periphery economies". They have been subordinated to the rules of neoliberal globalization and economic integration within the $\mathrm{EU}$, which give the greatest potential for action and benefits to transnational capital, especially MNCs.

The explanatory strengths of both theories in CEE are complementary and therefore not simply substitutable one for the other. Consequently, greater dialog between them may have significant cognitive values. A manifestation of this possibility is the postulates of broader inclusion in VoC research in the postcommunist countries of the issues raised in the polemics of the advocates of the world-system theory with supporters of neoclassical economics and the modernization theory. They mainly include the role and function of the state, the characteristics of the main actors of systemic changes, and their behavior, considering capitalist development in terms of both modernization (increase in competitiveness) and regress, e.g., creating new hierarchies of subordination and in-depth analysis of foreign investment patterns, including their impact for the state and economy of the host countries - the distribution of benefits, structural consequences, etc. [Bluhm, 2010; King, 2010]. There are other areas of research important for CEE also indicated. "Further investigation may reveal a number of underlying long-term cultural and political factors (the role of corruption, the relationship between the citizen and the state, the strength of public institutions, the rule of law, social dialogue, and so on) that have an important impact on the prospect of economic convergence" [Farkas, 2016, p. 486]. ${ }^{10}$ Indicating the direction of such research results to a large extent from the need to overcome the weaknesses and limitations of the VoC approach. Among them, there is the adopted economic balance model, among other things, the functionalistic character of the VoC approach focusing on explaining the results, but not the causes of the institutions, as well on institutional determinism diminishing the role of systemic contradictions and conflicts, and also interests of the social actors. Some of VoC's weaknesses are, however, a result of accelerating the pace and complexity of systemic changes that in the study of capitalism create many new challenges, also in the sphere of economic coordination and institutional or social changes.

One can illustratively point out several issues that already have a modifying effect on the VoC approach as well as on other research perspectives dealing with the comparative modern economy. Broadening the

10 The author has made an attempt to include some of the suggested issues in a book about the Polish model of capitalism shaped after the collapse of the communist system, see Jasiecki [2013]. 
issues and incorporating further groups of economies and research traditions creates new theoretical challenges that affect both the theory and the methodology, changing the nature and scope of our knowledge. The crisis of capitalism and liberal democracy together with global economic changes limit the value of theoretical concepts based on old generalizations. The increase in the role of new variants of capitalism, especially in Asia (but not only), is going beyond the VoC assumptions. ${ }^{11}$ At the same time, new technologies, artificial intelligence, and demographic trends are radically changing the nature of work and the market mechanism as a whole. Generally, this is the problem of the new form of capitalism, and in the long run it may be the transformation of capitalism into some other system form with a completely different institutional shape. Will it be capitalism within today's meaning? What will be the labor market? What will the digital proletariat be doing? [Reich, 2015]. In this sense, the VoC approach, as suggested by Hall and Soskice, should be considered primarily as a program for future searches, rather than a ready "theory of everything”.

\section{References}

Amable, B. (2003), The diversity of modern capitalism, Oxford University Press, Oxford.

Ash, T. G. (1989), The uses of adversity: essays on the fate of Central Europe, Granta Books, Cambridge.

Asian Capitalism. (2013). Bringing Asia into the comparative capitalism perspective, Socio-Economic Review, Vol. 11, No. 2, special issue.

Aslund, A., (2008), How capitalism was built. The transformation of Central and Eastern Europe, Russia, and Central Asia, Cambridge University Press, New York.

Bałtowski, M., Kwiatkowski, E. (2018), Przedsiębiorstwa państwowe we wspótczesnej gospodarce, PWN, Warszawa. Berend, I. T. (1996), Central and Eastern Europe 1944-1993. Detour from the Periphery, University Press, Cambridge. Blaszczyk, B. (2016), Odwracanie prywatyzacji w Polsce i na Węgrzech, Economic Studies, No 4 (XCI), pp. 527-553.

Bluhm, K. (2010), Theories of capitalism put to the test: introduction to a debate on Central and Eastern Europe, Historical Social Research/Historische Sozialforschung, Vol. 35, No. 2 (132), pp. 197-217.

Bluhm, K., Martens, B., Trappmann, V. (red.) (2014), Business leaders and new varieties of capitalism in Post-Communist Europe, Routledge, London and New York.

Bohle, D., Greskovits, B. (2012), Capitalist diversity on Europe's periphery. Cornell studies in political economy, Cornell University Press, Ithaca - London.

Carothers, T. (2002), The end of transition paradigm, Journal of Democracy, pp. 5-21.

Castells, M., Himanem, P. (2002), The information society and the welfare state: the finish, Press University, Oxford.

Dahrendorf, R., (1990), Reflections on the revolution in Europe, Times Books, Random House, New York.

Eyal, G., Szelenyi, I., Townsley, E. (1998), Making capitalism without capitalists: class formation and elite struggles in post-communist Europe, Verso, London.

Farkas, B. (2016), Models of capitalism in the European Union. Post-crisis perspective, Palgrave, Macmillan, London.

Federowicz, M. (2004), Różnorodność kapitalizmu. Instytucjonalizm i doświadczenie zmiany ustrojowej po komunizmie, IFiS PAN, Warszawa.

Grosse, T. (2016), Tragedia państw peryferyjnych, czyli o geopilitycznych dylematach Polski w Unii Europejskiej, in: T. Zarycki (Ed.). Polska jako peryferie, Scholar, Warszawa, pp. 25-50.

Hall, P. A., Gingerich, D. W. (2004), Varieties of capitalism and institutional complementarities in the macroeconomy. An empirical analysis, in: MPifG discussion paper, Max Planck Institute for the Study of Societies, Cologne.

Hall, P.A., Soskice, D. (2001), Varieties of capitalism: the institutional foundations of comparative advantage, University Press, Oxford.

Hancke, B., Rhodes, M., Thatcher, M. (2009), Beyond varieties of capitalism, in: B. Hancke (Ed.), Debating varieties of capitalism. A reader, University Press, Oxford, pp. 273-300.

Hancke, B., Rhodes, M., Thatcher, M. (Eds.) (2007), Conflict, contradictions, and complementaries in the European economy, University Press, Oxford.

Holzer, J., Balik, S. (2009), Postkomunistyczne reżimy niedemokratyczne. Badania nad przemianami teorii politycznej w okresie po transformacji ustrojowej, Ośrodek Myśli Politycznej, Wyższa Szkoła Biznesu - National-Louis University, Kraków-Nowy Sącz

11 See the special issue: Asian capitalism. Bringing Asia into the comparative capitalism perspective. "Socio-Economic Review" 2013, vol. 11 no 2. 
Iankova, E. A. (2010), Central and Eastern European capitalism: a critical perspective on the varieties of capitalism approach for its analysis, Emecon. Employment and economy in Central and Eastern Europe, Vol. 1, retrieved from http://www. emecon.eu/current-issue/debatte/iankova/.

Inglehart, R. F., Norris, P. (2016), Trump, brexit, and the rise of populism: economic have-nots and cultural backlash, Harvard Kennedy School, Harvard.

Jasiecki, K. (2013), Kapitalizm po polsku. Między modernizacja a perypetiami Unii Europejskiej, IFiS PAN, Warszawa.

Jasiecki, K. (2016), Nowa peryferyjność w perspektywie różnorodności kapitalizmu. Przykład posocjalistycznych państw Unii Europejskiej (A new peripherality in the perspective of the diversity of capitalism. An example of post-socialist European Union countries), in: T. Zarycki (Ed.), Polska jako peryferie, Scholar, Warszawa, pp. 51-72.

King, L. (2007), Central European capitalism in comparative perspective, in: B. Hancké, M. Rhodes, M. Thatcher (Eds.), Beyond varieties of capitalism. conflict, contradictions, and complementarities in the European economy, University Press, Oxford, pp. 308-327.

King, L. (2010), The role of existing theories and the need for a theory of capitalism in Central Eastern Europe, Emecon. Employment and economy in Central and Eastern Europe, Vol. 1, www.emecon.eu/King.

King, L., Szelenyi, I. (2005), Post-communist economic systems, in: N. J. Smelser, R. Swedberg (Eds.), The handbook of economic sociology, University Press, Princeton, pp. 205-232.

Lane, D., Myant, M.(2007). Varieties of capitalism in post-communist countries, Palgrave Macmillan, New York.

Lubbe, A. (2010), Transformacja, modernizacja czy po prostu normalizacja? Wybory modelu gospodarki polskiej po 1989 roku, in: W. Morawski (Ed.), Modernizacja Polski: Struktury, Agencje, Instytucje, Wydawnictwo Akadmickie i Profesjonalne, Akademia Leona Koźmińskiego, Warszawa, pp. 54-89.

McMenamin, I. (2004), Varieties of capitalist democracy: what difference does East-Central Europe make? Journal of Public Policy, 24, pp. 259-274.

Mendelski, M. (2010), The varieties of capitalism approach goes east: institutional complementarities and law enforcement during post-communist transition, in: A. Krause, V. Trappman (Eds.), What capitalism? Socio-economic change in Central Eastern Europe, Universitat Jena, Jena, pp. 8-44.

Miller, R. M. (2010), Latin American business history and varieties of capitalism, Business History Review, 84, pp. 653-657.

Muller, J.-W. (2017), What is populism, University of Pennsylvania Press, Philadelphia.

Myant, M., Drahokoupil, J. (2011), Transition economies: political economy in Russia, Eastern Europe and Central Asia, Wiley \& Sons, Hoboken.

Nolke, A., Vliegenthart, A. (2009), Enlarging the varieties of capitalism: the emergence of dependent market economies in East Central Europe, World Politics, Vol. 4, pp. 670-702.

North, D. C. (2003), Pojmowanie zmian ekonomicznych I wzrostu gospodarczego (Understanding Economic Change and Economic Growth), in: G. W. Kołodko (Ed.), Globalizacja, Marginalizacja, Rozwój, WWSPiZ, Warszawa, pp. 137-152.

Offe, C. (1996), Varieties of transition. The East European and the East German experience, Polity Press, Cambridge.

Próchniak, M., Rapacki, R., Gardawski J., Czerniak A. (2016), The emerging models of capitalism in CEE11 countries - a tentative comparison with Western Europe, Warsaw Forum of Economic Sociology, Vol. 7, No. 2 (14) Autumn, pp. 7-70. Przeworski, A. (1995), Sustainable democracy, Cambridge University Press, Cambridge.

Reich, R. (2015), Saving capitalism, Icon Books, Omnibus Business Centre, London.

Schmidt, V. A., Thatcher, M. (Eds.), Resilient liberalism in Europe's political economy, University Press, Cambridge.

Schneider, M. S., Paunescu, M. (2012), Changing varieties of capitalism and revealed comparative advantages from 1990 to 2005: a test of the Hall and Soskice claims, Socio-Economic Review, Vol, 10, No. 4, pp. 731-753.

Sosnowska, A. (2004)., Zrozumieć zacofanie. Spory historyków o Europę Wschodnia (1947-1994), Trio, Warszawa.

Stark, D. (1996), Recombinant property in East European capitalism, American Journal of Sociology, Vol. 101, pp. 993-1027.

Szacki, J. (1994), Liberalizm po komunizmie, Znak, Kraków.

Tridico, P. (2011), Institutions, human development and economic growth in transition economies, Palgrave, London.

Vytautas, K. (2011), What type of capitalism do the Baltic countries belong to? Emecon. Employment and economy in Central and Eastern Europe, Vol. 1, retrieved from http://www.emecon.eu/current-issue/second/vytautas-kuokstis/.

Willis, K. (2005), Theories and practices of development, Routledge, London.

Witt, M. A., Redding, G. (2013), Asian business systems: institutional comparison, clusters and implications for varieties of capitalism and business systems theory, Socio-Economic Review, Vol. 11, No. 2, 1 pp. 265-300.

Wnuk-Lipiński, E., Ziółkowski, M. (2001), Pierwsza dekada niepodległości. Próba socjologicznej syntezy, ISP PAN, Warszawa.

Wojtyna, A. (2005), Alternatywne modele kapitalizmu, in: S. Lis (red.), Dylematy wyboru modelu rozwoju gospodarczego Polski, Akademia Ekonomiczna, Kraków, pp. 83-107.

Zhang, X., Whitley, R. (2013), Changing macro-structural varieties of East Asian capitalism, Socio-Economic Review, Vol. 11, No. 2, pp. 301-336.

Zielonka, J. (2018), Counter - revolution. Liberal Europe in retreat, University Press, Oxford. 